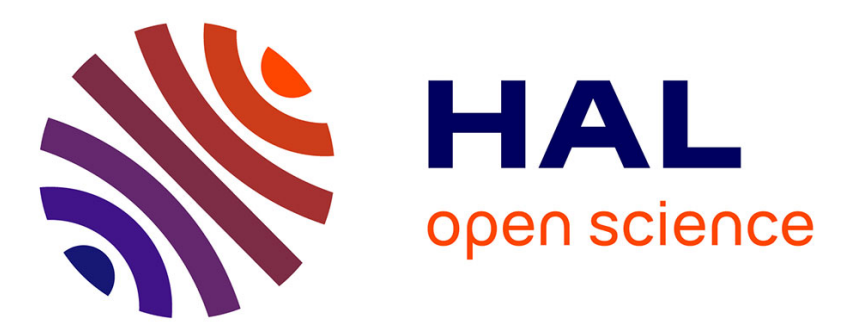

\title{
Purinergic receptors: new targets for the treatment of gout and fibrosis
}

Thomas Gicquel, Brendan Le Daré, Elisabeth Boichot, Vincent Lagente

\section{To cite this version:}

Thomas Gicquel, Brendan Le Daré, Elisabeth Boichot, Vincent Lagente. Purinergic receptors: new targets for the treatment of gout and fibrosis. Fundamental \& Clinical Pharmacology, 2017, 31 (2), pp.136-146. 10.1111/fcp.12256 . hal-01508430

\section{HAL Id: hal-01508430 \\ https://hal-univ-rennes1.archives-ouvertes.fr/hal-01508430}

Submitted on 14 Apr 2017

HAL is a multi-disciplinary open access archive for the deposit and dissemination of scientific research documents, whether they are published or not. The documents may come from teaching and research institutions in France or abroad, or from public or private research centers.
L'archive ouverte pluridisciplinaire HAL, est destinée au dépôt et à la diffusion de documents scientifiques de niveau recherche, publiés ou non, émanant des établissements d'enseignement et de recherche français ou étrangers, des laboratoires publics ou privés. 


\section{Purinergic receptors: new targets for the treatment of gout and fibrosis}

Thomas Gicquel $^{\mathrm{a}, \mathrm{b}}$, Brendan Le Dare $\mathrm{e}^{\mathrm{b}, \mathrm{c}}$, Elisabeth Boichot ${ }^{\mathrm{b}}$, Vincent Lagente ${ }^{\mathrm{b}}$

a. CHU Rennes, Laboratoire de toxicologie biologique et médico-légale, F-35033 Rennes, France.

b. UMR991 INSERM, Université Rennes 1, Faculté de Pharmacie, F-35043 Rennes, France

c. CHU Rennes, Pôle Pharmacie, F-35033 Rennes, France.

Correspondence:

Thomas Gicquel, Laboratoire de toxicologie biologique et médico-légale, CHU Pontchaillou, F-35033 Rennes, France. thomas.gicquel@ chu-rennes.fr

Running title: Treatment of fibrosis targeting purinergic receptors

Keywords: Purinergic receptors, ATP, P2X7, inflammation, fibrosis, NLRP3-inflammasome 


\begin{abstract}
Adenosine triphosphate is involved in many metabolic reactions, but it has also a role as a cellular danger signal transmitted through purinergic receptors (PRs). Indeed, ATP can bind to PRs which are found in the membrane of many cell types, although the relative proportions of the receptor subtypes differ. PRs are classified according to genetic and pharmacological criteria and especially their affinities for agonists and their transduction mechanism (i.e. as metabotropic P2YRs or ionotropic P2XRs).
\end{abstract}

Extracellular ATP release by activated or necrotic cells may activate various PRs and especially P2X7R, the best-characterized PR, on immune cells. P2X7R is known to regulate the activation of the Nod-like receptor (NLR)-family protein, NLRP3 inflammasome, which permit the release of IL-1 $\beta$, a potent pro-inflammatory cytokine. The P2X7R/NLRP3 pathway is involved in many inflammatory diseases, such as gout, and in fibrosis diseases associated with inflammatory process, liver or lung fibrosis.

Some authors imaging also a real promising therapeutic potential of P2X7R blockage. Thus several pharmaceutical companies have developed P2X7R antagonists as novel antiinflammatory drug candidates. Clinical trials of the efficacy of these antagonists are now underway. A better understanding of the P2X7R/NLRP3 signalling pathways permits the identification of targets and the development of a new class of drugs able to inhibit the fibrogenesis process and collagen deposition. 


\section{Abbreviations}

ASC

ECM

FGFR

IL

IPF

MMP

$\mathrm{NASH}$

NSAID

NLRP

PDGFR

PRs

TIMP

TNF

VEGFR
Apoptosis speck-like protein containing a CARD

Extracellular matrix

Fibroblast growth factor receptor

interleukin

Idiopathic Pulmonary Fibrosis

Matrix metalloproteinase

Non-alcoholic steatosis hepatitis

Non-steroidal anti-inflammatory drugs

NOD-, LRR-, and pyrin domain-containing

Platelet derived growth factor receptor

Purinergic receptors

Tissue inhibitor of metalloproteinase

Tumor Necrosis Factor

Vascular endothelial growth factor receptors 


\section{Introduction}

Purinergic receptors (PRs) have been described to bind purine bases, the constituents of nucleosides and nucleotides. In vivo, the most important nucleotide is adenosine 5'triphosphate (ATP) - recognized by its critical involvement in metabolism, immunity, pain signalling and inflammation. However, ATP can also serve as a cellular danger signal. Recent research indicates that purinergic receptors, mainly $\mathrm{P} 2 \mathrm{X} 7 \mathrm{R}$, have a key role in the release of interleukin (IL)-1 $\beta$, a pro-inflammatory cytokine involved in chronic inflammation associated with fibrogenesis processes such as pulmonary fibrosis, rheumatoid arthritis, gout and asthma involving the activation of inflammasome signalling pathway [1-5].

A better understanding of the purinergic receptor signalling pathways and progress in medicinal chemistry research has enabled the synthesis of potent antagonists for PRs. The characterization of these drug targets could well lead to the development of a new class of drugs able to inhibit the fibrogenesis process and collagen deposition.

\section{Adenosine-5'-triphosphate}

The nucleotide ATP is composed of a purine base (adenine), a ribose sugar ( $\beta$-Dribofuranose) and a 3' phosphate group. Its main function is to store, transport and supply energy for the cell's chemical reactions. ATP molecules are generated during cellular respiration and eliminated during biosynthesis, mobility and cell division. Hydrolysis of ATP to form ADP or AMP releases the energy contained in the pyrophosphate bonds. Although ATP's role in energy metabolism has long been known, it is now clear that nucleotides and nucleosides also have a role in extracellular signalling [6].

Several studies have shown that extracellular ATP and its receptors are involved in many pathophysiological processes, including chronic pain [7], inflammation [8], cell shrinkage, ion transport, chemotaxis, neurotransmission and danger signalling [9]. Extracellular ATP has several characteristics that render it a potent danger signal: a high intracellular concentration, a low extracellular concentration, hydrophilicity, and ubiquitous degradation (by ectoATPase). Lastly, ATP has many specific receptors with different affinities [10]. Thus, the extracellular release of ATP can act as a danger signal via several mechanisms. 
ATP molecules are stored in the cytosol at concentrations between 1 and $5 \mathrm{mM}$, whereas the extracellular ATP concentration is much lower, in the nanomolar range. The release of ATP generates a chemotactic gradient that in turn recruits immune cells [11]. Mechanical, infectious or hypoxic stress and cell damage can trigger the extracellular release of ATP - a danger signal that is tightly regulated by various transporters and enzymes.

Once released into the extracellular space, ATP has an extremely short half-life and is rapidly broken down into ADP, AMP and adenosine by ecto-enzymes located in membranes or extracellular space [12]. In healthy tissue, ATP release is tightly regulated, and its extracellular concentration is maintained at a low level by ATP/ADPases. This balance disappears during inflammatory processes because as pro-inflammatory mediators trigger ATP release and down-regulate the expression of ATP/ADPases [5].

Abnormal cell activation may provide a signal that alerts the immune system to danger, triggering innate immunity activation leading to inflammatory process and remodelling. In this context, dying cells release danger signals that may activate the immune system and stimulate innate and adaptive immunity.

\section{Purinergic receptors}

Extracellular nucleotides like ATP can bind to purinergic receptors on the cell surface. Purinergic receptors are found in all cell types, although the relative proportions of the receptor subtypes differ. The PRs have an important role in pain and inflammatory response [13]. In vertebrates, PRs are classified according to genetic and pharmacological criteria and especially their affinities for agonists: the P1Rs are selective adenosine receptors and the P2Rs preferentially bind ATP and ADP [14]. Endogenous and synthetic agonists of purinergic receptors were reported in Table I.

\section{P1Rs}

The P1Rs are G-protein-coupled adenosine receptors that contain a seven-transmembranehelix domain. There are four P1Rs in humans: A1, A2a, A2b and A3 [15]. Adenosine is the only agonist of these metabotropic receptors. The P1Rs' N-terminal and C-terminal regions are respectively extracellular and intracellular, which enables signal transduction. The A1 and 
$\mathrm{A} 3$ receptors are coupled to a $\mathrm{Gi}$ protein, while the $\mathrm{A} 2 \mathrm{a}$ and $\mathrm{A} 2 \mathrm{~b}$ receptors are coupled to a Gs protein [16]. Adenosine and its receptors are known to be involved in immunity, inflammation and carcinogenesis $[17,18]$.

\section{P2Rs}

In 1994, Abbracchio and Burnstock suggested that the P2Rs should be subclassified according to their transduction mechanism (i.e. as metabotropic P2YRs or ionotropic P2XRs) [19].

\section{P2YRs}

In mammals, the metabotropic P2YRs (P2YR1-2-4-6-11-12-13-14) have been divided into 8 subtypes [20]. The structure is typical of G-protein-coupled receptors, with seven transmembrane domains (328 to 377 amino acids in length) linked by disulphide bridges.

The P2YRs can be activated by various purine or pyrimidine diphosphate or triphosphate nucleotides (conjugated to sugars, in some cases) (Table I). The pharmacology of the P2YRs is complex because these receptors have a wide variety of cellular and tissue locations and many different ligands (ATP, UTP, ADP, UDP, UDP-glucose, etc.) [15]. P2Y2 is particularly involved in innate immunity. The binding of ATP to the P2Y2R triggers a chemoattractant signal that is absent in P2Y2 knock-out mice [21]. P2Y2R activation also triggers the release of pro-inflammatory cytokines (such as IL- 6 and IL- 8) by epithelial cells [22].

\section{P2XRs}

There are seven subtypes of ionotropic P2XRs (P2X1-7), all of which have a single physiological agonist (ATP). These ligand-gated ion channel receptors display $30 \%$ to $50 \%$ of amino acid homology [6].

Human P2XRs are composed of subunits of 379 to 595 amino acids in length [23]. Two hydrophobic transmembrane domains (M1 and M2) are separated by an ectodomain within which 10 cysteine residues form disulphide bridges. The ectodomain contains an ATP binding site, intracellular N- and C-terminal regions and a kinase binding site [24].

Activation of the extracellular domain of P2XR requires the binding of least three ATP molecules [23]. The P2X receptors differ in their affinity for ATP and its analogues. 
The P2XR exist as homotrimers or heteromers and are only functional when three subunits are bound together [25]. Many combinations are possible: heteromeric $\mathrm{P} 2 \mathrm{X}_{1 / 2}, \mathrm{P} 2 \mathrm{X}_{1 / 4}, \mathrm{P} 2 \mathrm{X}_{1 / 5}$, $\mathrm{P} 2 \mathrm{X}_{2 / 3}, \mathrm{P} 2 \mathrm{X}_{2 / 6}, \mathrm{P} 2 \mathrm{X}_{4 / 6}$ and $\mathrm{P} 2 \mathrm{X}_{4 / 7}[26]$.

During prolonged stimulation by an agonist, the P2XRs can undergo conformational changes that increase the ion channel's permeability [27]. The trimers then form a non-selective cation channel that is permeable to large ions. This ion flux changes the intracellular ion concentration and thus the membrane potential [28].

P2XR activation may be followed by a desensitization period, the duration of which varies from one subtype to another. P2XRs are generally classified in rapidly desensitizing (P2X1 and P2X3) and slowly or non-desensitizing (P2X2, P2X4, P2X5 and P2X7) receptors [29]. For example, $\mathrm{P} 2 \mathrm{X} 7 \mathrm{R}$ is a non-desensitizing receptor; the pore stays open as long it is bound by ATP [30]. The P2XRs' activity may also be regulated by $\mathrm{pH}$, certain xenobiotics and ions [28].

Among P2XRs, the P2X7R seems to be the most involved in the inflammatory response. Indeed this receptor play a central role in inflammatory pain and inflammatory diseases (Crohn's disease, gout or rheumatoid arthritis for example) and his activation lead to the release of inflammatory cytokines, such as TNF- $\alpha$ or IL-1 $\beta$, mediated by the inflammasome pathway [31].

\section{P2X7R}

In mammals, P2X7R (formerly known as P2Z) is widely distributed throughout the body, and especially on nerve cells, hematopoietic cells, and myeloid cells such as monocytes or macrophages [32]. The genes encoding the P2X7 and P2X4 subunits are both located on chromosome 12. The P2X7 and P2X4 subunits share a high degree of amino acid sequence homology and can form heterotrimers with each other.

P2X7R has a lower affinity for ATP than the other P2XRs do. 2'(3')-O-(4-benzoylbenzoyl) adenosine-5'-triphosphate (BzATP) is the most potent synthetic agonist for P2X7R [33]. Activation of P2X7 is modulated by local ion concentrations [34]. The responses to ATP are potentiated in a low-Ca ${ }^{2+}$ or low- $\mathrm{Mg}^{2+}$ environment. Hence, $\mathrm{ATP}^{4-}$ is probably the active form of ATP that binds to the P2X7R [35]. 
Once activated, the P2X7R can form homo- or heterotrimers, and at least ten isoforms have been identified in humans especially $\mathrm{P} 2 \mathrm{X}_{1 / 2}, \mathrm{P} 2 \mathrm{X}_{1 / 4}, \mathrm{P} 2 \mathrm{X}_{1 / 5}, \mathrm{P} 2 \mathrm{X}_{2 / 3}, \mathrm{P} 2 \mathrm{X}_{2 / 6}, \mathrm{P} 2 \mathrm{X}_{4 / 6}$ and $\mathrm{P} 2 \mathrm{X}_{4 / 7}$ $[26,28,36]$.

Interestingly, P2X7R has a longer C-terminal domain than the other P2XRs, which appears to facilitate interactions with intracellular proteins [37]. This structural difference also gives P2X7R the ability to form a wide, non-selective pore (allowing the passage of ions and compounds with a molecular weight of up to $900 \mathrm{Da}$ ) during prolonged ATP stimulation [38, 39].

\section{Role of P2X7R in the inflammasome signalling pathway}

Extracellular ATP release by activated or necrotic cells may activate various P2Rs and especially P2X7R on monocytes and macrophages. P2X7R stimulation by ATP induced potassium efflux, a production of Reactive Oxygen Species (ROS) from mitochondria and active inflammasome signalling pathway $[40,41]$.

The best-characterized inflammasome consists of three main components, the Nod-like receptor (NLR)-family protein, NLRP3, pro-caspase-1 and the ASC (Apoptosis speck-like protein containing a CARD) adapter, which bridge interactions between the former proteins [42]. NLRP3 activation requires two signals in macrophages. Cell priming with an NF- $\mathrm{B}$ activator, such as the TLR4-ligand LPS, is the first step of NLRP3 inflammasome activation leading to its own involvement [43]. The second signal includes a broad variety of activators, in which one the major pathway includes the P2X7 purinergic receptor. NLRP3 protein interacts with ASC and pro-caspase-1 and has an oligomerisation to become effective [43-45]. Following autoactivation via inflammasome assembly, caspase-1 cleaves pro-IL-1 $\beta$ in IL-1 $\beta$ (biologically active form) which are then secreted (Figure 1).

IL-1 $\beta$ is a cytokine with major roles in inflammation, innate immune response and fibrosis. This cytokine is produced by activated monocytes, macrophages and dendritic cells, inducing the production of chemokines or cytokines (such as TNF- $\alpha$ and IL-6) or proteases (such as matrix metalloproteinases (MMPs) and their tissue inhibitor (TIMPs)) associated with neutrophil recruitment and proliferation of resident cells mainly fibroblasts [46]. Since mature IL- $1 \beta$ is very potent, its production is tightly regulated by expression, transcription and secretion, especially by NLRP3 inflammasome [42]. 
Other P2Rs are known to be involved in the activation of NLRP3 inflammasome, including P2X4 [47], P2Y6 [48], P2Y2 and P1 adenosine receptors [17]. However, according to Burnstock et al. (2016), P2X7 appears to be the most involved receptor in inflammatory diseases and is thus the main anti-inflammatory drug target among the P2Rs [31].

\section{Involvement of inflammasome pathway in diseases}

The P2X7 receptor seems to be involved in many diseases including neurological, metabolic, gastrointestinal, respiratory, cancer, immune or inflammatory diseases [49-52]. Thus, several authors propose P2X7R as a new therapeutic target in such diseases. In this review, we developed only the diseases and treatments involving NLRP3 inflammasome and purinergic receptors.

\section{Gout}

Uric acid is a product of purine catabolism which is produced from injured tissue in vivo. At high local concentration, uric acid precipitates and forms crystals (monosodium crystals, or MSU) that cause inflammatory process as observed in gout. It was clearly demonstrated that the NLRP3 inflammasome is not only activated by extracellular ATP, indeed it can also be activated by MSU [42]. Indeed MSU is a danger signal activating P2X7R/NLRP3inflammasome pathway in gout arthritis $[42,53]$

It has also been shown that MSU can trigger the release of endogenous ATP and induce the expression of P2X7R [53]. This suggests that autocrine activation of P2Rs can occur in response to endogenous ATP release. High extracellular ATP concentrations have been detected in inflamed tissues, showing that ATP is a danger signal and P2X7R may be activated during a disease process when the ATP concentration locally increases or when ectonucleotidase levels are dysregulated [54]. Following internalization of MSU crystals, noneffective clearance leads to the production of ROS, potassium efflux, destabilization of the phagosome and rupture of the lysosome. This would ultimately result in the activation of caspase- 1 and the release of active pro-inflammatory cytokine IL-1 3 [40,53] (Figure 2).

P2X7R seems to be a potential key regulator of acute gout arthritis, and deficiencies in P2X7R/NLRP3 pathway can explain why some patients with uricemia never develop gout arthritis in their whole lives [4]. 


\section{Fibrosis}

Fibrosis is a basic connective tissue lesion defined by the increase of the fibrillar extracellular matrix components in a tissue or organ. This is a frequent component of a chronic inflammatory process but can also occur in other pathological conditions. The constitution of fibrosis is the result of a disruption of the balance of the extracellular matrix (ECM) : an increase of process synthesis and deposition of the components of the ECM on one hand and a decrease of their degradation on the other hand [55].

Pulmonary fibrosis is a severe and crippling disease with a poor prognosis. Its main histological features include alveolar septal lesions, abnormal reepithelialization, fibroblast proliferation and excessive deposition of ECM due to abnormal wound healing, and inflammation characterized by an influx of immune cells. Idiopathic pulmonary fibrosis (IPF) is the most frequent form of interstitial pneumonia of unknown etiology [56-57]. It has been assumed that IPF is the consequence of chronic inflammation [58].

No curative treatment was actually available for IPF however two drugs were recently marketed for IPF treatment: pirfenidone and nintedanib. The earliest studies on pirferidone were conducted in the 1990s using a pulmonary fibrosis model in hamster. The researchers have been shown that this drug could reduce the expression of several profibrotic factors such as TGF- $\beta$, hydroxyproline or procollagen I and III, in this model. More recently, experiments on human lung cells indicated a decrease in fibroblast proliferation and lowered levels of fibrotic and inflammatory markers with this treatment. Pirfenidone has also both antiinflammatory and anti-fibrotic effects even if the link between inflammation and fibrosis is still a subject of debate. Clinical trials confirmed these results and revealed a positive outcome in terms of mortality [59-61].

Nintedanib was discovered in 2006 and developed as a potent angiogenesis inhibitor. Indeed nintedanib was found to have a specific inhibitory profile against three tyrosine kinase receptors, namely platelet derived growth factor receptor (PDGFR) $\alpha$ and $\beta$, vascular endothelial growth factor receptors (VEGFR-1,-2, and -3), and fibroblast growth factor receptor 1 (FGFR-1). These properties prevented fibroblast proliferation, myofibroblast transformation, inflammatory cells recruitment and collagen accumulation in mice and human lung models. Moreover, a lower incidence of acute IPF exacerbations and promising results on fibrosis progression was observed in clinical trials [60-62]. N-acetylcysteine (NAC), a 
mucolytic drug with antioxidant mechanism of action was also claimed to possess antifibrotic properties. However, recent studies proved that this drug is clinically ineffective in IPF treatment $[60,63]$.

Using an experimental model of pulmonary fibrosis in mice, it was observed an induction of fibrosis markers such as lung collagen content, metalloproteinases (MMPs) or tissue inhibitor of metalloproteinases (TIMPs). Furthermore, it has been demonstrated that uric acid locally produced in the lung upon bleomycin-induced DNA damage and degradation induced the activation of the NLRP3-inflammasome pathway and IL-1 $\beta$ production, such as in gout [39, 42]. Uric acid released injured cells exposed to bleomycin constitute a major endogenous danger signal that activates the NLRP3 inflammasome leading to lung inflammation and fibrosis.

In this model, $\mathrm{P} 2 \mathrm{X} 7$ receptor-deficient (P2X7R KO) mice presented dramatically reduced lung inflammation and fibrosis, showing the role of P2X7 receptor in this disease [2]. Moreover, pulmonary fibrotic patients presented increased ATP content in bronchoalveolar lavage fluid (BALF) in comparison with control individuals. It has been observed an early increase in ATP levels in BALF on bleomycin administration in mice and modulation of ATP levels with the ATP-degrading enzyme apyrase greatly reduced bleomycin-induced inflammatory cell recruitment, lung IL-1 $\beta$, and TIMP-1 production [2]. Hence, ATP released from injured cells constitutes a major endogenous danger signal that engages $\mathrm{P} 2 \mathrm{X}(7)$ receptor activation leading to IL-1 $\beta$ maturation and lung fibrosis [55].

Similarly to that observed for pulmonary fibrosis, there is growing evidence supporting that purinergic signaling is also involved in the development of liver fibrosis [64]. Hepatic fibrosis develops following chronic inflammatory process under the influence of repeated stimulation. The first step is characterized by an inflammatory phase: hepatocytes are activated and recruit $\mathrm{T}$ cells while the biliary epithelial cells activate resident macrophages called Kupffer cells of the liver. The result is a production of free radicals and cytokines such as TNF- $\alpha$, IL- 6 or IL$1 \beta$, after inflammasome pathway activation, which is to stimulate hepatic stellate cells and lead to their transformation $[55,65]$. Following the first step, a second fibrotic phase where the quiescent stellate cells turn into myofibroblasts and lead to the apoptosis of hepatocytes. This induces an accumulation of fibrotic cells such activated stellate cells and myofibroblasts from fibrocytes differentiation. These cells also induce the recruitment of immune cells responsible for chronic inflammation, IL-1 $\beta$ and inflammasome pathway have been reported 
to play an important role in chronic liver inflammation leading to fibrosis and cirrhosis [66]. This fibrogenic process is associated with MMPs/TIMPs imbalance which produces excessive components of the ECM.

Using the $\mathrm{CCl}_{4}$-preclinical experimental model of experimental liver fibrosis, a significant increase in P2X7R expression was observed [55]. The role of P2X7R has also been implicated in the Kupffer cell activation and inflammation, following the release of ATP from necrosed cells in a CCl4-induced model of NASH [67]. The involvement of P2X7 is also supported by the study showing that $\mathrm{P} 2 \mathrm{X} 7$ receptor blockade attenuates mouse liver fibrosis [68]. Thus P2X7 receptor might play a key role in the modulation of the cell fate in NASH [69].

Treatment with glucocorticoids, which are the most potent anti-inflammatory drugs, did not have the expected improving effects on the development of pulmonary fibrosis [70]. That is why developing new therapeutic target is necessary.

\section{Possible treatment}

Some authors imaging a real promising therapeutic potential of $\mathrm{P} 2 \mathrm{XR}$ antagonists. P2R blockade is already applied therapeutically. In fact, the P2Y12 ADP receptor has a key role in platelet activation. In humans, the P2Y12R antagonists clopidogrel (Plavix $®$ ), ticagrelor (Brilique $\left.{ }^{\circledR}\right)$ and prasugrel (Efient $\left.{ }^{\circledR}\right)$ acts as antiplatelet agents. They are thus indicated for the prevention of atherothrombotic events, such as myocardial infarction, ischemic stroke and peripheral arterial disease [71]. P2Rs are therefore targets of interest in the search for novel therapeutics in general and new anti-inflammatory drugs in particular.

Furthermore, it has been shown in vitro that treatment with P2X7R antagonists (A-74003 and A- 438079) inhibits inflammatory process in response to ATP or MSU crystals [40, 53]. The positive effects of P2X7R antagonists on inflammatory diseases are due to inhibition of the signalling cascade involving the inflammasome and IL-1 $\beta[72,73]$. These results confirm that P2X7R blockage is a drug target for reducing inflammation in human. Moreover, some studies have shown that $\mathrm{P} 2 \mathrm{X} 7$ blockage, such as $\mathrm{P} 2 \mathrm{X} 7 \mathrm{R} \mathrm{KO}$ mice or $\mathrm{P} 2 \mathrm{X} 7 \mathrm{R}$ antagonists treated-mice were protected from inflammatory pain $[7,52,73]$.

The characterization of the involvement of the P2R-NLRP3-inflammasome pathway has opened a large possibility of new therapeutic targets for inflammation but also for the reduction of collagen deposition and fibrosis [55]. Indeed, Huang et al. (2014) showed that 
the development of liver injury and fibrosis is prevented using a specific P2X7R antagonist, A438079 reduces CCl4-induced cell infiltration, production of pro-inflammatory cytokines and collagen accumulation in the liver [68].

In recent years, many pharmaceutical companies have developed compounds for treating chronic inflammatory diseases [74, 75]. In particular, P2X7R antagonists have been developed by Astra Zeneca (AZ11645373; AZD9056; AZ11645373 and AZ10606120), Pfizer (ES- 224.535) and GlaxoSmithKline (GSK314181A) [75, 76]. Some of these compounds have shown good preclinical results and have entered clinical development. For example, a Phase II trial of the P2X7R antagonist AZD9056 (400 mg/day) reported statistically significant efficacy (vs. placebo) in the treatment of rheumatoid arthritis at one month. However, despite good tolerance, efficacy was no longer observed at six months [77]. Similarly, EC-224.535 was no more effective than placebo in the treatment of rheumatoid arthritis in methotrexate-resistant patients [78]. These several preclinical studies have reported encouraging data on inflammatory disease and may be used as fibrosis treatment. Indeed P2X7R antagonists are able to block the activation of the inflammasome pathway independently of the mechanisms of action of the other pharmacological treatments (for example nintedanib or pirfenidone). Co-administration of these potential anti-fibrotic drugs could also provide additional benefits for patients suffering from fibrotic diseases. The screening of potential drugs effective in preclinical models of fibrosis would be the next challenge. However, it is not excluded that blockade of one type of receptors, such as P2X7R, may induce a compensation by others ( $\mathrm{P} 2 \mathrm{X} 4 \mathrm{R}$ for example).

Clinical trials targeting P2X7R continue also in cancerology $[79,80]$ and P2Rs are being studied as potential anti-inflammatory drugs [76], painkillers [7] and even treatments for diabetes [49], multiple sclerosis [81], Alzheimer's disease [82], duchenne muscular dystrophy [83], retinal degeneration [84] or cancer [80, 85]. 


\section{Conclusion}

ATP has many vital functions in vivo, including danger signal. This molecule can bind to a large number of receptors. Among them, P2X7R is attracting extensive interest in the field of inflammation. Selective and available tools are necessary to validate the right target and develop effective therapeutics. Regarding the recent data, P2X7 receptor would be a good candidate.

Although the initial data on the efficacy of P2X7R antagonists in the treatment of rheumatoid arthritis are not convincing, the search for orally administered compounds for blockade of the P2R/IL-1 $\beta$ axis continues. These findings indicate that P2X7R blockade may be a target for prevention and treatment of fibrosis diseases associated with inflammatory process.

\section{Acknowledgments}

The authors thank Ahmad Sharanek and David Fraser (Biotech Communication) for English corrections. 


\section{Tables}

Table I : Purinergic receptors, agonists and their intracellular signalling mechanisms.

\begin{tabular}{|c|c|c|c|c|}
\hline \multicolumn{2}{|c|}{ Type of receptor } & Endogenous & Specific synthetic & Type of signalling \\
\hline \multirow{7}{*}{ P2XRs } & $\mathrm{P} 2 \mathrm{X} 1$ & \multirow{7}{*}{ ATP } & BzATP & \multirow{7}{*}{ ion-channel-linked receptors } \\
\hline & $\mathrm{P} 2 \mathrm{X} 2$ & & 2-MeSATP & \\
\hline & $\mathrm{P} 2 \mathrm{X} 3$ & & $\alpha, \beta-M e S A T P$ & \\
\hline & $\mathrm{P} 2 \mathrm{X} 4$ & & $\alpha, \beta$-MeATP & \\
\hline & $\mathrm{P} 2 \mathrm{X} 5$ & & ATP $\gamma \mathrm{S}$ & \\
\hline & $\mathrm{P} 2 \mathrm{X} 6$ & & - & \\
\hline & $\mathrm{P} 2 \mathrm{X} 7$ & & BzATP & \\
\hline \multirow{8}{*}{ P2YRs } & $\mathrm{P} 2 \mathrm{Y} 1$ & ADP & MRS 2365 & \multirow{8}{*}{ G-protein-coupled receptors } \\
\hline & $\mathrm{P} 2 \mathrm{Y} 2$ & \multirow{2}{*}{ ATP, UTP } & MRS 2698 & \\
\hline & $\mathrm{P} 2 \mathrm{Y} 4$ & & 2'-azido-dUTP & \\
\hline & P2Y6 & UDP & MRS 2693, UDP $\beta S$ & \\
\hline & P2Y11 & ATP & ARC 67085MX & \\
\hline & $\mathrm{P} 2 \mathrm{Y} 12$ & ADP & 2-MeSADP & \\
\hline & P2Y13 & ADP & 2-MeSADP & \\
\hline & $\mathrm{P} 2 \mathrm{Y} 14$ & $\begin{array}{c}\text { UDP, } \\
\text { UDP-glucose }\end{array}$ & MRS 2690 & \\
\hline \multirow{4}{*}{$\begin{array}{l}\text { Adenosine } \\
\text { receptors }\end{array}$} & A1 & \multirow{4}{*}{ Adenosine } & R-PIA, CPA & \multirow{4}{*}{ G-protein-coupled receptors } \\
\hline & $\mathrm{A} 2_{\mathrm{A}}$ & & CGS21680 & \\
\hline & $\mathrm{A} 2_{\mathrm{B}}$ & & MRS 3997 & \\
\hline & A3 & & IB-MECA & \\
\hline
\end{tabular}

\section{Figure legends}

Figure 1. Extracellular release of IL- $1 \beta$, following stimulation of the P2X7R by ATP

Figure 2. IL-1 $\beta$ production and NLRP3 inflammation activation following stimulation by MSU (monosodium urate) 


\section{References}

1. Di Virgilio F. P2X receptors and inflammation. Curr. Med. Chem. (2015) 22 866-77.

2. Riteau N., Gasse P., Fauconnier L., Gombault A., Couegnat M., Fick L., Kanellopoulos J., Quesniaux V.F., Marchand-Adam S., Crestani B., Ryffel B., Couillin I. Extracellular ATP is a danger signal activating P2X7 receptor in lung inflammation and fibrosis. Am. J. Respir. Crit. Care Med. (2010) 182 774-83.

3. Portales-Cervantes L.., Niño-Moreno P., Salgado-Bustamante M., García-Hernández M.H., Baranda-Candido L., Reynaga-Hernández E., Barajas-López C., González-Amaro R., Portales-Pérez D.P. The His155Tyr (489C $>$ T) single nucleotide polymorphism of P2RX7 gene confers an enhanced function of P2X7 receptor in immune cell. Cell Immunol. (2012) 276 168-175.

4. Tao J.H., Zhang Y., Li X.P. P2X7R: a potential key regulator of acute gouty arthritis. Semin. Arthritis Rheum. (2013) 43 376-380.

5. Idzko M., Hammad H., van Nimwegen M., Kool M., Willart M.A., Muskens F., Hoogsteden H.C., Luttmann W., Ferrari D., Di Virgilio F., Virchow J.C. Jr, Lambrecht B.N. Extracellular ATP triggers and maintains asthmatic airway inflammation by activating dendritic cells. Nat. Med. (2007) 13 913-919.

6. Burnstock G., Knight G.E., Greig A.V.H. Purinergic Signaling in Healthy and Diseased Skin. J. Invest. Dermatol. (2012) 132 526-546.

7. King B.F. Novel P2X7 receptor antagonists ease the pain. Br. J. Pharmacol. (2007) 151 565-567.

8. Boué-Grabot E., Akimenko M.A., Séguéla P. Unique functional properties of a sensory neuronal P2X ATP-gated channel from zebrafish. J. Neurochem. (2000) 75 1600-1607.

9. Mariathasan S., Weiss D.S., Newton K., McBride J., O'Rourke K., Roose-Girma M., Lee W.P., Weinrauch Y., Monack D.M., Dixit V.M. Cryopyrin activates the inflammasome in response to toxins and ATP. Nature (2006) 440 228-232.

10. la Sala A., Ferrari D., Di Virgilio F., Idzko M., Norgauer J., Girolomoni G. Alerting and tuning the immune response by extracellular nucleotides. J. Leukocyte Biol. (2003) 73 339-343.

11. Bours M.J., Swennen E.L., Di Virgilio F., Cronstein B.N., Dagnelie P.C. Adenosine 5'triphosphate and adenosine as endogenous signaling molecules in immunity and inflammation. Pharmacol. Ther. (2006) 112 358-404.

12. Velasquez S., Eugenin E.A. Role of Pannexin-1 hemichannels and purinergic receptors in 
the pathogenesis of human diseases. Front. Physiol. (2014) 596.

13. Surprenant A., North R.A. Signaling at purinergic P2X receptors. Annu. Rev. Physiol. (2009) $71333-359$.

14. Ralevic V., Burnstock G. Receptors for purines and pyrimidines. Pharmacol. Rev. (1998) 50 413-492.

15. Junger W.G. Immune cell regulation by autocrine purinergic signalling. Nat. Rev. Immunol. (2011) 11 201-212.

16. Lazarowski E.R., Boucher R.C. Purinergic receptors in airway epithelia. Curr. Opin. Pharmacol. (2009) 9 262-267.

17. Baron L., Gombault A., Fanny M., Villeret B., Savigny F., Guillou N., Panek C., Le Bert M., Lagente V., Rassendren F., Riteau N., Couillin I. The NLRP3 inflammasome is activated by nanoparticles through ATP, ADP and adenosine. Cell Death Dis. (2015) 6 :e1629.

18. Antonioli L., Blandizzi C., Pacher P., Haskó G. Immunity, inflammation and cancer: a leading role for adenosine. Nat. Rev. Cancer (2013) 13 842-857.

19. Abbracchio M.P., Burnstock G. Purinoceptors : are there families of P2X and P2Y purinoceptors? Pharmacol. Ther. (1994) 64 445-475.

20. Boeynaems J.M., Communi D., Gonzalez N.S., Robaye B. Overview of the P2 receptors. Semin. Thromb. Hemost. (2005) 31 139-149.

21. Elliott M.R., Chekeni F.B., Trampont P.C., Lazarowski E.R., Kadl A., Walk S.F., Park D., Woodson R.I., Ostankovich M., Sharma P., Lysiak J.J., Harden T.K., Leitinger N., Ravichandran K.S. Nucleotides released by apoptotic cells act as a find-me signal to promote phagocytic clearance. Nature (2009) 461 282-286.

22. Kruse R., Säve S., Persson K. Adenosine triphosphate induced P2Y2 receptor activation induces proinflammatory cytokine release in uroepithelial cells. J. Urol. (2012) 188 24192425 .

23. Jarvis M.F., Khakh B.S. ATP-gated P2X cation-channels. Neuropharmacology (2009) 56 208-215.

24. Burnstock G. Purine and pyrimidine receptors. Cell Mol. Life Sci. (2007) 64 1471-1483.

25. Nicke A., Bäumert H.G., Rettinger J., Eichele A., Lambrecht G., Mutschler E., Schmalzing G. P2X1 and P2X3 receptors form stable trimers: a novel structural motif of ligand-gated ion channels. EMBO J. (1998) 17 3016-28. 
26. Guo C., Masin M., Qureshi O.S., Murrell-Lagnado R.D. Evidence for functional P2X4/P2X7 heteromeric receptors. Mol. Pharmacol. (2007) 72 1447-1456.

27. Khakh B.S., Bao X.R., Labarca C., Lester H.A. Neuronal P2X transmitter-gated cation channels change their ion selectivity in seconds. Nat. Neurosci. (1999) 2322-330.

28. Khakh B.S., North R.A. P2X receptors as cell-surface ATP sensors in health and disease. Nature (2006) 442 527-532.

29. Saul A., Hausmann R., Kless A., Nicke A. Heteromeric assembly of P2X subunits. Front Cell Neurosci. (2013) 7250.

30. Ferrari D., Pizzirani C., Adinolfi E., Lemoli R.M., Curti A., Idzko M., Panther E., Di Virgilio F. The P2X7 receptor: a key player in IL-1 processing and release. J. Immunol. (2006) $1763877-83$.

31. Burnstock G. P2X ion channel receptors and inflammation. Purinergic Signal. (2016) 12 59-67.

32. Burnstock G., Knight G.E. Cellular distribution and functions of P2 receptor subtypes in different systems. Int. Rev. Cytol. (2004) 240 31-304.

33. Gever J.R., Cockayne D.A., Dillon M.P., Burnstock G., Ford. A. Pharmacology of P2X channels. Eur. J. Physiol. (2006) 452 513-537.

34. Rassendren F., Buell G.N., Virginio C., Collo G., North R.A., Surprenant A. The permeabilizing ATP receptor, P2X7. Cloning and expression of a human cDNA. J. Biol. Chem. (1997) 272 5482-5486.

35. Surprenant A., Rassendren F., Kawashima E., North R.A., Buell G. The cytolytic P2Z receptor for extracellular ATP identified as a P2X receptor (P2X7). Science (1996) 272 735-738.

36. Nicke A., Kuan Y.H., Masin M., Rettinger J., Marquez-Klaka B., Bender O. A functional P2X7 splice variant with an alternative transmembrane domain 1 escapes gene inactivation in P2X7 knock-out mice. J. Biol. Chem. (2009) 284 25813-25822.

37. Kim M., Jiang L.H., Wilson H.L., North R.A., Surprenant A. Proteomic and functional evidence for a P2X7 receptor signalling complex. EMBO J. (2001) 20 6347-6358.

38. Steinberg T.H., Silverstein S.C. Extracellular ATP4- promotes cation fluxes in the J774 mouse macrophage cell line. J. Biol. Chem. (1987) 262 3118-22.

39. Locovei S., Scemes E., Qiu F., Spray D.C., Dahl G. Pannexin1 is part of the pore forming unit of the P2X7 receptor death complex. FEBS Lett. (2007) 581 483-488. 
40. Gicquel T., Victoni T., Fautrel A., Robert S., Gleonnec F., Guezingar M., Couillin I., Catros V., Boichot E., Lagente V. Involvement of purinergic receptors and NLRP3inflammasome pathway in the ATP-induced cytokine release from macrophages. Clin. Exp. Pharmacol. Physiol. (2014) 41 279-286.

41. Gicquel T., Robert S., Victoni T., Lagente V. The NLRP3 inflammasome: Physiopathology and therapeutic application. Presse Med. (2016) 45 438-446.

42. Martinon F., Pétrilli V., Mayor A., Tardivel A., Tschopp J. Gout-associated uric acid crystals activate the NALP3 inflammasome. Nature (2006) 440 237-241.

43. Bauernfeind F., Ablasser A., Bartok E., Kim S., Schmid-Burgk J., Cavlar T., Hornung V. Inflammasomes: current understanding and open questions. Cell Mol. Life Sci. (2011) 68 765-783.

44. Bauernfeind F., Bartok E., Rieger A., Franchi L., Núñez G., Hornung V. Cutting edge: reactive oxygen species inhibitors block priming, but not activation, of the NLRP3 inflammasome. J. Immunol. (2011) 187 613-617.

45. Schroder K., Zhou R., Tschopp J. The NLRP3 inflammasome: a sensor for metabolic danger ? Science (2010) 327 296-300.

46. Gasse P., Riteau N., Charron S., Girre S., Fick L., Pétrilli V., Tschopp J., Lagente V., Quesniaux V.F., Ryffel B., and Couillin I. Uric acid is a danger signal activating NALP3 inflammasome in lung injury inflammation and fibrosis. Am. J. Respir. Crit. Care Med. (2009) 179 903-913.

47. Seil M., El Ouaaliti M., Fontanils U., Etxebarria I.G., Pochet S., Dal Moro G., Marino A., Dehaye J.P. Ivermectin-dependent release of IL-1beta in response to ATP by peritoneal macrophages from P2X(7)-KO mice. Purinergic Signal (2010) 4 405-416.

48. Uratsuji H., Tada Y, Kawashima T., Kamata M., Hau C.S., Asano Y., Sugaya M., Kadono T., Asahina A., Sato S., Tamaki K. P2Y6 receptor signaling pathway mediates inflammatory responses induced by monosodium urate crystals. J. Immunol. (2012) 188 436-444.

49. Vergani A., Fotino C., D'Addio F., Tezza S., Podetta M., Gatti F., Chin M., Bassi R., Molano R.D., Corradi D., Gatti R., Ferrero M.E., Secchi A., Grassi F., Ricordi C., Sayegh M.H., Maffi P., Pileggi A., Fiorina P. Effect of the purinergic inhibitor oxidized ATP in a model of islet allograft rejection. Diabetes (2013) 62 1665-1675.

50. Cao S.H., Yuan S.P., Hou Q. Advance in the research on P2X7 and inflammatory respiratory diseases. Yao Xue Xue Bao. (2013) 48 1183-1188.

51. Baudelet D., Lipka E., Millet R., Ghinet A. Involvement of the P2X7 purinergic receptor in inflammation: an update of antagonists series since 2009 and their promising 
therapeutic potential. Curr. Med. Chem. (2015) 22 713-729.

52. Abdel-Magid AF. Promising Therapeutic Potential of P2X7 Modulators. ACS Med. Chem. Lett. (2016) 7 348-350.

53. Gicquel T., Robert S., Loyer P., Victoni T., Bodin A., Ribault C., Gleonnec F., Couillin I., Boichot E., Lagente V. IL-1 $\beta$ production is dependent of the activation of purinergic receptors and NLRP3 pathway in human macrophages. FASEB J. (2015) 29 4162-4173.

54. Lenertz L.Y., Gavala M.L., Zhu Y., Bertics P.J. Transcriptional control mechanisms associated with the nucleotide receptor $\mathrm{P} 2 \mathrm{X} 7$, a critical regulator of immunologic, osteogenic, and neurologic functions. Immunol. Res. (2011) 50 22-38.

55. Robert S., Gicquel T., Victoni T., Valenca S.S., Barreto E., Bailly-Maitre B., Boichot E., Lagente V. Involvement of matrix metalloproteinases (MMPs) and inflammasome pathway in molecular mechanisms of fibrosis. Biosci. Rep. (2016) pii: BSR20160107.

56. Selman M., King T.E., Pardo A. Idiopathic pulmonary fibrosis: prevailing and evolving hypotheses about its pathogenesis and implications for therapy. Ann. Int. Med. (2001) 134 136-151.

57. Katzenstein A.L., Myers J.L. Idiopathic pulmonary fibrosis: clinical relevance of pathologic classification. Am. J. Respir. Crit. Care Med. (1998) 157 1301-1315.

58. Ward P.A., Hunninghake G.W. Lung inflammation and fibrosis. Am. J. Respir. Crit. Care Med. (1998) 157 S123-S129.

59. Lehtonen S.T., Veijola A., Karvonen H., Lappi-Blanco E., Sormunen R., Korpela S., Zagai U., Sköld M.C., Kaarteenaho R. Pirfenidone and nintedanib modulate properties of fibroblasts and myofibroblasts in idiopathic pulmonary fibrosis. Respir. Res. (2016) 17 14.

60. Myllärniemi M., Kaarteenaho R. Pharmacological treatment of idiopathic pulmonary fibrosis - preclinical and clinical studies of pirfenidone, nintedanib, and $\mathrm{N}$-acetylcysteine. Eur. Clin. Respir. J. (2015) 226385.

61. Hughes G., Toellner H., Morris H., Leonard C., Chaudhuri N. Real World Experiences: Pirfenidone and Nintedanib are Effective and Well Tolerated Treatments for Idiopathic Pulmonary Fibrosis. J Clin Med. (2016) 59.

62. Hostettler K.E., Zhong J., Papakonstantinou E., Karakiulakis G., Tamm M., Seidel P., Sun Q., Mandal J., Lardinois D., Lambers C., Roth M. Anti-fibrotic effects of nintedanib in lung fibroblasts derived from patients with idiopathic pulmonary fibrosis. Respir Res. (2014) 15157.

63. Rogliani P., Calzetta L., Cavalli F., Matera M.G., Cazzola M. Pirfenidone, nintedanib and $\mathrm{N}$-acetylcysteine for the treatment of idiopathic pulmonary fibrosis: A systematic review 
and meta-analysis. Pulm. Pharmacol. Ther. (2016) 40 95-103.

64. Lu D., Insel P.A. Cellular Mechanisms of Tissue Fibrosis. Purinergic signaling and response in fibroblasts and tissue fibrosis. Am. J. Physiol. Cell Physiol. (2014) 306 C779-C788.

65. Friedman S.L. Liver fibrosis - from bench to bedside. J. Hepatol. (2003) 38 38-53.

66. Szabo G., Csak T. Inflammasomes in liver diseases. J. Hepatol. (2012) 57 642-654.

67. Chatterjee S., Rana R., Corbett J., Kadiiska M.B., Goldstein J., Mason R.P. P2X7 receptor-NADPH oxidase axis mediates protein radical formation and Kupffer cell activation in carbon tetrachloride-mediated steatohepatitis in obese mice. Free Radic Biol Med. (2012) 52 1666-1679.

68. Huang C., Yu W., Cui H., Wang Y., Zhang L., Han F., Huang T. P2X7 blockade attenuates mouse liver fibrosis. Mol. Med. Rep. (2014) 9 57-62.

69. Chatterjee S., Das S. P2X7 Receptor as a Key Player in Oxidative Stress-Driven Cell Fate in Nonalcoholic Steatohepatitis. Oxid. Med. Cell Longev. (2015) 172493.

70. Kolb M., Bonniaud P., Galt T., Sime P.J., Kelly M.M., Margetts P.J., Gauldie J. Differences in the fibrogenic response after transfer of active transforming growth factorbetal gene to lungs of "fibrosis-prone" and "fibrosis-resistant" mouse strains. Am. J. Respir. Cell Mol. Biol. (2002) 27 141-150.

71. Briasoulis A, Telila T, Palla M, Siasos G, Tousoulis D. P2Y12 receptor antagonists: which one to choose? A systematic review and meta-analysis. Curr. Pharm. Des. (2016)

72. Weber FC, Esser PR, Müller T, Ganesan J, Pellegatti P, Simon M.M., Zeiser R., Idzko M., Jakob T., Martin S.F. Lack of the purinergic receptor P2X7 results in resistance to contact hypersensitivity. (2010) J. Exp. Med. 207 2609-2619.

73. Honore P., Donnelly-Roberts D., Namovic M., Zhong C., Wade C., Chandran P., Zhu C., Carroll W., Perez-Medrano A., Iwakura Y., Jarvis M.F. The antihyperalgesic activity of a selective P2X7 receptor antagonist, A-839977, is lost in IL-1alphabeta knockout mice. Behav. Brain Res. (2009) 204 77-81.

74. Pelegrin P. Targeting interleukin-1 signaling in chronic inflammation: focus on $\mathrm{P} 2 \mathrm{X}(7)$ receptor and Pannexin-1. Drug News Perspect. (2008) 21 424-433.

75. Arulkumaran N., Unwin R.J., Tam F.W. A potential therapeutic role for P2X7 receptor (P2X7R) antagonists in the treatment of inflammatory diseases. Expert Opin. Investig. Drugs (2011) 20 897-915.

76. Mehta N., Kaur M., Singh M., Chand S., Vyas B., Silakari P., Bahia M.S., Silakari O. Purinergic receptor $\mathrm{P}_{2} \mathrm{X}_{7}$ : a novel target for anti-inflammatory therapy. Bioorg. Med. Chem. (2014) 22 54-88. 
77. Keystone E.C., Wang M.M., Layton M., Hollis S., McInnes I.B.; D1520C00001 Study Team. Clinical evaluation of the efficacy of the $\mathrm{P} 2 \mathrm{X} 7$ purinergic receptor antagonist AZD9056 on the signs and symptoms of rheumatoid arthritis in patients with active disease despite treatment with methotrexate or sulphasalazine. Ann. Rheum. Dis. (2012) 71 1630-5.

78. Stock T.C., Bloom B.J., Wei N., Ishaq S., Park W., Wang X. Efficacy and safety of CE224,535 , an antagonist of $\mathrm{P} 2 \mathrm{X} 7$ receptor, in treatment of patients with rheumatoid arthritis inadequately controlled by methotrexate. J. Rheumatol. (2012) 39 720-727.

79. Cesaro A., Brest P., Hofman V., Hébuterne X., Wildman S., Ferrua B., Marchetti S., Doglio A., Vouret-Craviari V., Galland F., Naquet P., Mograbi B., Unwin R., Hofman P. Amplification loop of the inflammatory process is induced by $\mathrm{P} 2 \mathrm{X} 7 \mathrm{R}$ activation in intestinal epithelial cells in response to neutrophil transepithelial migration. Am. J. Physiol. Gastrointest. Liver Physiol. (2010) 299 G32-42.

80. Hofman P., Cherfils-Vicini J., Bazin M., Ilie M., Juhel T., Hébuterne X., Gilson E., Schmid-Alliana A., Boyer O., Adriouch S., Vouret-Craviari V. Genetic and pharmacological inactivation of the purinergic P2RX7 receptor dampens inflammation but increases tumor incidence in a mouse model of colitis-associated cancer. Cancer Res. (2015) 75 835-845.

81. Yiangou Y., Facer P., Durrenberger P., Chessell I.P., Naylor A., Bountra C., Banati R.R., Anand P. COX-2, CB2 and P2X7-immunoreactivities are increased in activated microglial cells/macrophages of multiple sclerosis and amyotrophic lateral sclerosis spinal cord. BMC Neurol. (2006) 612.

82. Ryu J.K., McLarnon J.G. Block of purinergic P2X(7) receptor is neuroprotective in an animal model of Alzheimer's disease. Neuroreport (2008) 19 1715-1719.

83. Sinadinos A., Young C.N., Al-Khalidi R., Teti A., Kalinski P., Mohamad S., Floriot L., Henry T., Tozzi G., Jiang T., Wurtz O., Lefebvre A., Shugay M., Tong J., Vaudry D., Arkle S., doRego J.C., Górecki D.C. P2RX7 purinoceptor: a therapeutic target for ameliorating the symptoms of duchenne muscular dystrophy. PLoS Med. (2015) 12 e1001888.

84. Reichenbach A., Bringmann A. Purinergic signaling in retinal degeneration and regeneration. Neuropharmacology. (2016) 104 194-211.

85. Roger S., Jelassi B., Couillin I., Pelegrin P., Besson P., Jiang L.H. Understanding the roles of the $\mathrm{P} 2 \mathrm{X} 7$ receptor in solid tumour progression and therapeutic perspectives. Biochim. Biophys. Acta. (2015) 1848 2584-602. 


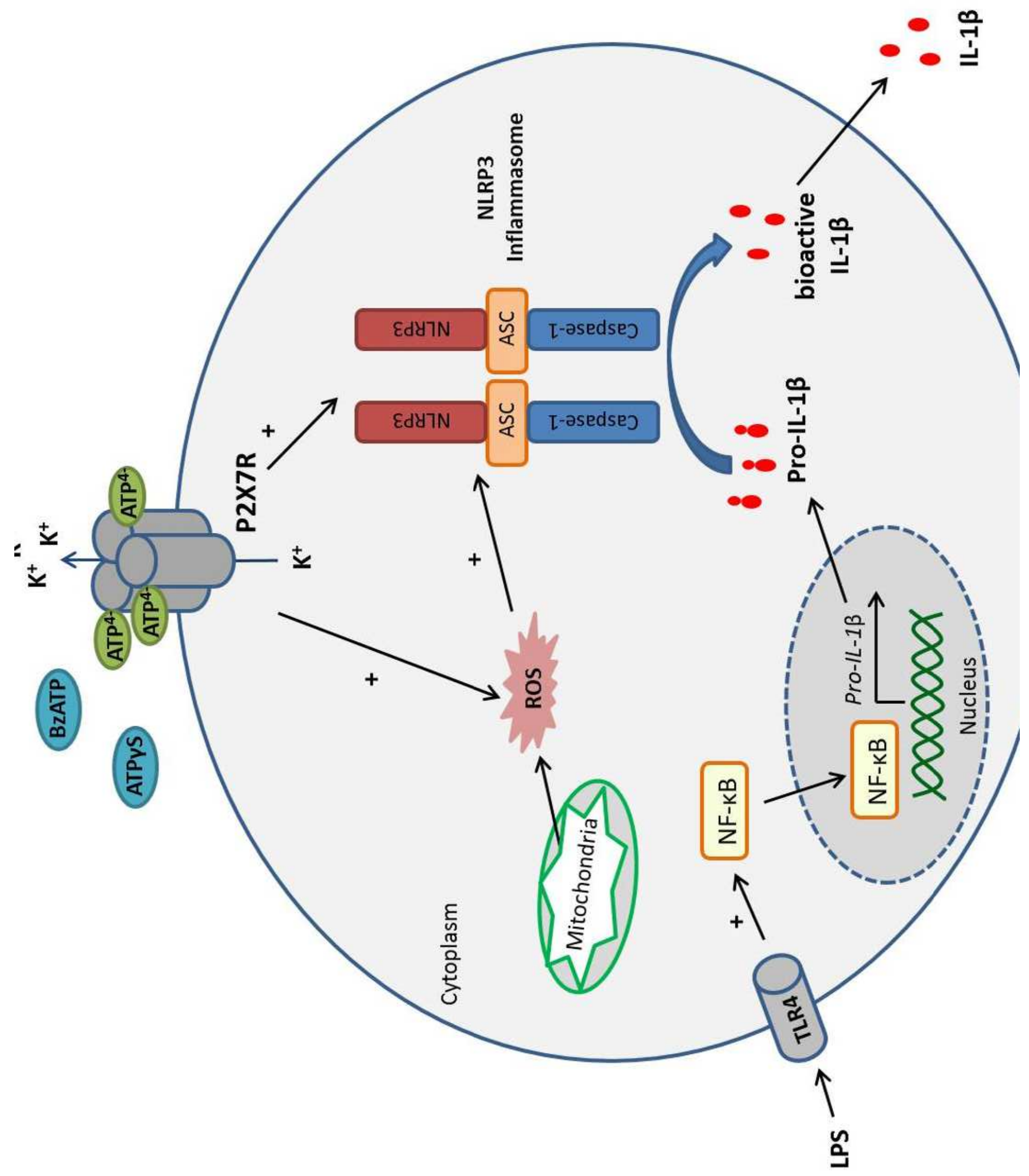




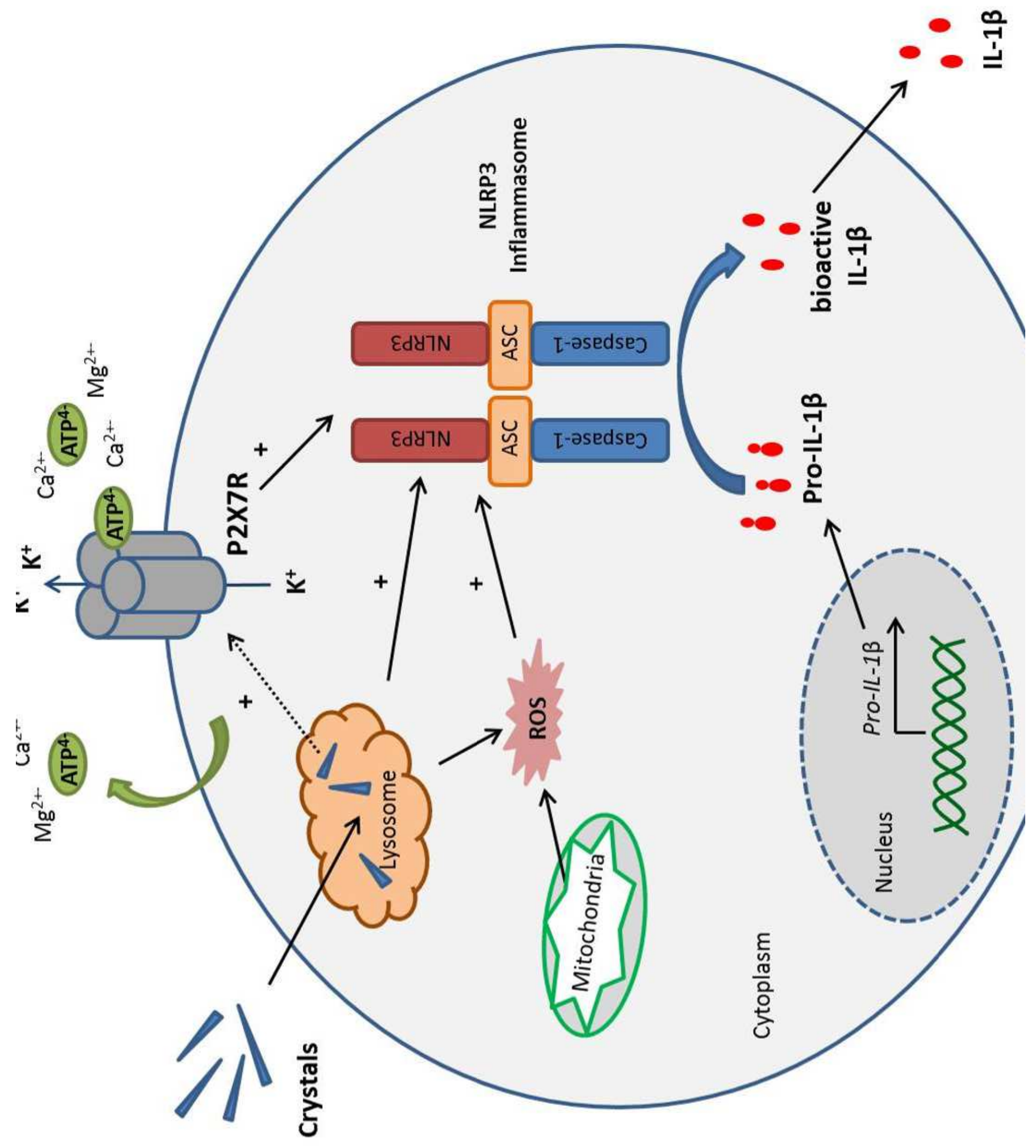

